\title{
Rootstock Effects on Growth and Flowering in Young Apple Trees Grown with Ammonium and Nitrate Nitrogen
}

\author{
Yong-Ping Gao, Hino Motosugi, and Akira Sugiura \\ Laboratory of Pomology, Faculty of Agriculture, Kyoto University, Kyoto 606, Japan
}

Additional index words. dwarfing rootstock, Malus prunifolia var. ringo, cytokinin, gibberellin

\begin{abstract}
Ungrafted trees of seven apple rootstock cultivars, M.4, M.7, M.11, M.26, M.27, MM.106, and Maru. bakaidou (Malus prunifolia Borkh. var. ringo Asami; weeping type), and 'Fuji' (Malus domestics Borkh.) trees grafted on these seven plus M.9 and M. 16 rootstock were grown in sand. They were regularly supplied with nutrient solutions of $\mathrm{N}$ as ammonium alone (A), nitrate alone (T), and both (AT). With both ungrafted and grafted trees, the shoot growth of six rootstock (M.11, M.4, M.7, MM.106, M.26, and M.27) was significantly less with A than with T. With 'Fuji' trees grafted on the above six rootstock, the number of flowering buds and the ratios of flowering buds to total emerged buds were significantly enhanced by treatments A and AT, especially in the formation of axillary flowering buds. Flowering and shoot growth of 'Fuji' trees grafted on M. prunifolia and M.16 were slightly affected by the form of supplied $\mathrm{N}$. In the xylem sap, cytokinin-like activity was detected in a single zone in paper chromatography in all rootstock and 'Fuji' trees. The activity in six ungrafted rootstock (M.4, M.7, M.11, M.26, M.27, and MM.106) and 'Fuji' trees grafted on these plus M.9 rootstock were higher with A than with T. Gibberellin-like activity in the same sap was detected in two zones, Rfs 0.3 to 0.4 and Rfs 0.7 to 0.8 in paper chromatography. In the six ungrafted rootstock and in 'Fuji' trees grafted on these plus M.9, A led to higher activity at Rfs 0.7 to $0 . S$, but $\mathrm{T}$ led to higher activity at $\mathrm{Rfs} 0.3$ to 0.4 . Cytokinin-like and gibberellin-like activities in ungrafted $M$. prunfolia and 'Fuji' trees grafted on M. prunifolia or M.16 were not affected by the form of $\mathrm{N}$.
\end{abstract}

Growth and flowering of apple trees "are profoundly influenced by the amount, time, and form of $\mathrm{N}$ applied. Ammonium nitrogen supplied in solution culture restricts vegetative growth and enhances flowering in 'Jonathan' apples, while nitrate nitrogen has the opposite 'effect (Grasmanis and Edwards, 1974; Grasmanis and Leeper, 1965, 1967). Shear and Faust (1971) also observed the same type of flowering response to ammonium nitrogen in 'York Imperial' apple trees.

Many size-controlling rootstock have been introduced and are used worldwide. In Japan, Marubakaidou has been used as the most important standard rootstock, although being vigorous, it has the advantages of high rooting ability and excellent adaptability to wet soils (Lee et al., 1982; Sadamori and Murakami, 1952) and tolerance to disease and high manganese concentration. Dwarfing rootstock, such as M.9, M.26, and MM. 106, have been replacing this rootstock in high-density plantings. However, detailed comparisons of growth and flowering responses of rootstock of varying vigor to $\mathrm{N}$ form have not been reported. Grasmanis and his coworkers $(1965,1967,1971,1974)$ compared the effectiveness of $\mathrm{N}$ forms with only MM. 104 and Northern Spy rootstock.

Endogenous hormones, which are mainly produced in roots, are important in the development of aerial parts of many plant species. In apple (Malus domestics Borkh.) trees, the presence of gibberellin-like and cytokinin-like substances in xylem sap has been demonstrated (Greene, 1975; Ibrahim and Dana, 1971; Jones, 1973; Jones and Lacey, 1968), and those levels have been associated with scion vigor and/or flowering (Ibrahim and Dana, 1971; Jones, 1986; Lockard and Schneider, 1981). A similar relationship has been demonstrated with citrus and sweet cherry [Prunus avium (L.) L.] (Saidha et al., 1983; Stevens and Westwood, 1984). Further, fertilization with ammonium nitro-

\footnotetext{
Received for publication 28 May 1991. Accepted for publication 9 Oct. 1991. The cost of publishing this paper was defrayed in part by the payment of page charges. Under postal regulations, this paper therefore must be hereby marked advertisement solely to indicate this fact.
}

gen has been found to temporarily increase zeatin concentration in the xylem sap of M.7 rootstock (Buban et al., 1978).

We describe here the growth responses of young, potted, ungrafted rootstock cultivars and the growth and flowering responses of 'Fuji' trees grafted on various rootstock of varying vigor to $\mathrm{N}$ fed either as ammonium, nitrate, or both forms in sand culture. Second, cytokinin-like and gibberellin-like activities in the xylem sap of those trees in response to $\mathrm{N}$ forms are characterized.

\section{Materials and Methods}

Plant materials. Two sand culture experiments were conducted with ungrafted rootstock in 1985 and grafted trees in 1986. In the former experiment, trees of seven rootstock cultivars (M. prunifolia var. ringo, M.4, M.7, M.11, M.26, M.27, and MM. 106, all propagated by layering in 1984) were planted in coarse sand in 6-liter pots in Mar. 1985. They were pruned back to a height of $50 \mathrm{~cm}$, and the three uppermost buds were allowed to grow; the rest of the buds were removed.

In the experiment on grafting, 'Fuji' ('Rail's Janet' $\mathbf{x}$ 'Delicious') budwoods taken from established orchard trees were grafted to nine rootstock (M. prunfolia, M.4, M.7, M.9, M.11, M.16, M.26, M.27, or MM.106) in Spring 1985. Uniformly grafted trees were selected and planted in coarse sand in 10liter pots in Mar. 1986. They were also pruned back to a height of $50 \mathrm{~cm}$.

Treatments. Nitrogen was supplied as nitrate nitrogen from $\mathrm{Ca}\left(\mathrm{NO}_{3}\right)_{2}$ (treatment T), as ammonium from $\left(\mathrm{NH}_{4}\right)_{2} \mathrm{SO}_{4}$ (treatment $\mathrm{A}$ ), and with half of the $\mathrm{N}$ as nitrate and half as ammonium (treatment AT). Individual nutrient compositions and concentrations for each treatment (Table 1) were based on the work of Grasmanis and Edwards (1974), and total amounts of $\mathrm{N}$ an other macroelements were the same among these three treatments. Macroelement concentrations in 1986 were reduced to

Abbreviations: A, ammonium; AT, nitrate plus ammonium; T, nitrate. 
Table 1. Composition of macroelements in culture solutions.

\begin{tabular}{lccc}
\hline \hline & \multicolumn{3}{c}{ Treatments $\left(\mathrm{mg} \cdot\right.$ liter $\left.^{-1}\right)$} \\
\cline { 2 - 4 } Nutrients & $\mathrm{T}$ & $\mathrm{A}$ & $\mathrm{AT}$ \\
\hline$\left(\mathrm{NH}_{4}\right)_{2} \mathrm{SO}_{4}$ & --- & $528(264)^{2}$ & $264(132)$ \\
$\mathrm{Ca}\left(\mathrm{NO}_{3}\right)_{2} \cdot 4 \mathrm{H}_{2} \mathrm{O}$ & $944(472)$ & --- & $472(236)$ \\
$\mathrm{CaSO}_{4} \cdot 2 \mathrm{H}_{2} \mathrm{O}$ & --- & $688(344)$ & $344(172)$ \\
$\mathrm{K}_{2} \mathrm{HPO}_{4}$ & $174(87)$ & $174(87)$ & $174(87)$ \\
$\mathrm{MgSO}_{4} \cdot 7 \mathrm{H}_{2} \mathrm{O}$ & $370(185)$ & $370(185)$ & $370(185)$ \\
\hline
\end{tabular}

${ }^{7}$ Concentrations of macroelements used in 1986.

half the strength used in 1985. All solutions contained microelements as follows (in mg.liter ${ }^{-1}$ ): Fe, 3.0; B, 0.5; Mn, $0.5 ; \mathrm{Zn}, 0.05 ; \mathrm{Cu}, 0.02$; and $\mathrm{Mo}, 0.01$.

Ungrafted rootstock were supplied with $500 \mathrm{ml}$ of nutrient solution per pot twice a week from 10 Apr. to 30 Aug. 1985 and the grafted trees with 1 liter of the solution per pot twice a week from 10 Apr. to 30 Oct. 1986. Trees were watered additionally with clear well water during the experiment as needed. The $\mathrm{pH}$ of leaching solutions from the bottom of the pots tended to shift from $\approx 6$ to 7.5 after two applications of nitrate and to $\approx 5.5$ after the ammonium applications. With treatment AT, the $\mathrm{pH}$ was kept almost constant between 6.0 and 6.2. Therefore, by means of thoroughly washing the sand with well water the day before the next supply of nutrient solutions was applied, $\mathrm{pH}$ was kept nearly constant at 6.0 to 6.5 . Nitrate and ammonium ion concentration in the leaching solutions were monitored with an Ion Meter model 407A (Orion, Research, Cambridge, Mass.). Vitrification from ammonium was negligible in treatments A and AT.

In the first experiments, 20 to 25 trees of each rootstock cultivar were assigned to each of three $\mathrm{N}$ treatments, and five to seven trees were harvested for hormone analyses during 25 to $30 \mathrm{June}, 25$ to $30 \mathrm{July}$, and 25 to $30 \mathrm{Aug}$. In the second experiment, 15 to 20 'Fuji' trees grafted on each rootstock cultivar were assigned to each of three treatments, and five trees $\mathrm{m}$ each treatment were collected for hormone analyses from 25 to 30 July. The remaining 10 trees were supplied with nutrient solution until the end of" October and then adequately watered with well water until the following spring for observation of flowering.

Measurement of growth and flowering. In the first experiment, extension growth of the uppermost three shoots of 10 trees of each rootstock cultivar in each treatment was measured regularly during the treatment period. In the second experiment, total extension growth, number of side shoots, and internodal lengths in the middle section of the shoot were measured in winter on 10 trees grafted on each rootstock cultivar in each treatment. The number of flowering buds and the total number of emerged buds on these trees were counted at bloom in 1987, and the percentage of flowering buds relative to the total number of emerged buds was calculated. Data were subjected to an analysis of variance. Percentage data were transformed to arcsin before analysis. Mean separations were compared with Duncan's multiple range test.

Determinations of cytokinin- and gibberellin-like activity. On each sampling date, the aerial or scion parts of the trees were excised from the roots between 5:00 to 7:00 AM. After removing leaves and laterals, shoot stems were cut into $10-$ to $15-\mathrm{cm}-$ long segments and combined for five to seven trees (first experiment) or five trees (second experiment) per treatment. The segments were wrapped with wet filter paper to avoid moisture loss and kept in a refrigerator until xylem sap collection. The xylem sap was extracted by the vacuum-liquid displacement method of Moreno and Garcia-Martinez (1980). One strip of bark $\approx 2 \mathrm{~cm}$ wide was removed from each end of the shoot segments and rubber tubes were fitted to each end. The segment was placed upright through the rubber cap in a refrigerated suction bottle with a test tube inside. Water-saturated n-butanol was introduced into the upper rubber tube, and the vacuum was applied at the base by a water jet pump. Dripping fluid was collected in a test tube. N-butanol, three times the stem volume, was used for displacing xylem sap. The extracts were concentrated to dryness at $35 \mathrm{C}$ under reduced pressure, and the residue was dissolved in an appropriate amount of distilled water and stored at $-18 \mathrm{C}$ until analyzed.

A sample of extracts equivalent to $40 \mathrm{~g}$ of fresh weight of stems was adjusted to $\mathrm{pH} 2.5$ with $1 \mathrm{~N} \mathrm{HCl}$ and mixed with 1 $\mathrm{g}$ of insoluble polyvinylpolypyrolidone (PVPP) and filtered. The filtrate was put onto a $1.5 \times 30-\mathrm{cm}$ column packed with Dowex 50W X4 (50 to 100 mesh, $\mathrm{H}^{+}$form). After the column was successively washed with $50 \mathrm{ml}$ of water and $100 \mathrm{ml}$ of $70 \%$ ethanol, it was eluted with $100 \mathrm{ml}$ of $5 \mathrm{~N}$ ammonia in $35 \%$ ethanol. The eluate was evaporated to dryness at $35 \mathrm{C}$, and the residue was taken up in 2 to $3 \mathrm{ml}$ of $50 \%$ ethanol and streaked on a $4 \times 40-\mathrm{cm}$ strip of Toyo 51A paper (Toyo Roshi Kaisha, Tokyo). The paper was developed for $20 \mathrm{~cm}$ in 10 isopropanol :1 water :1 ammonia. After drying at room temperature, each paper was divided into 10 equal fractions, and each one was placed in a test tube that contained $2 \mathrm{ml}$ of $50 \%$ ethanol; these were kept overnight in a refrigerator. The extracts were transferred to plastic dishes $(35 \mathrm{~mm}$ diameter $\times 10 \mathrm{~mm}$ height $)$ provided with filter paper and dried at room temperature. $\mathrm{Cy}$ tokinin-like activity was assayed using an Amaranths betacyanin bioassay (Biddington and Thomas, 1973). N-(phenylmethyl)$1 \mathrm{H}$-purine-6-amine (BA) was used as a standard and the activity was converted into $\mu$ mol-equivalent BA.

Another sample of extract equivalent to $20 \mathrm{~g}$ of fresh weight of stems was mixed with $1 \mathrm{~g}$ of insoluble PVPP and filtered, adjusted to $\mathrm{pH} 2.5$, and extracted four times with ethyl acetate. The combined acidic ethyl acetate fraction was partitioned four times with $4 \% \mathrm{NaHCO}_{3}$. The alkaline aqueous fraction was washed three times with petroleum ether, adjusted to $\mathrm{pH} 2.5$, and partitioned four times with ethyl acetate. The acidic ethyl acetate fraction was evaporated at $35 \mathrm{C}$, and the residue was streaked onto a $4 \times 40-\mathrm{cm}$ strip of Toyo $51 \mathrm{~A}$ paper. The paper was developed for $20 \mathrm{~cm}$ with the solvent described above. After drying, the paper strip was cut into 10 equal segments, with one each placed into a test tube. Gibberellin-like activity was measured using a barley endosperm bioassay (Nicholls and Paleg, 1963). Authentic gibberellin $\left(\mathrm{GA}_{3}\right)$ was used as a standard, and the activity was converted into $\mu$ mol equivalent $\mathrm{GA}_{3}$.

In the experiment with ungrafted rootstock, data were transformed to logarithms for analysis of variance, then converted to the antilog for presentation. Among the three sampling periods, the activities of each rootstock in each of three treatments were similar. Therefore, each date of the three sampling periods were regarded as a replication, and the means were compared using Duncan's multiple range test. In the experiment with grafted trees, however, no statistical analysis was done because determinations were not replicated.

\section{Results}

Ungrafted rootstock. The extension growth of ungrafted rootstock was measured regularly, but only the data at the end of the treatment period (25 Aug.) are shown (Table 2). With 
Table 2. Mean growth of three shoots of seven ungrafted rootstock fed with T, A, or AT.

\begin{tabular}{lccccccc}
\hline \hline & \multicolumn{7}{c}{ Mean growth of three shoots (cm) } \\
\cline { 2 - 8 } $\mathrm{N}$ & form $^{2} \mathrm{M} \cdot \mathrm{p}^{\mathrm{y}}$ & $\mathrm{M} .11$ & M.4 & M.7 & MM.106 & M.26 & M.27 \\
\hline $\mathrm{T}$ & $129 \mathrm{a}^{\mathrm{x}} \mathrm{D}^{\mathrm{w}}$ & $87 \mathrm{bB}$ & $81 \mathrm{cB}$ & $117 \mathrm{cc}$ & $129 \mathrm{cD}$ & $70 \mathrm{cA}$ & $71 \mathrm{bA}$ \\
$\mathrm{AT}$ & $125 \mathrm{aF}$ & $85 \mathrm{bC}$ & $70 \mathrm{bB}$ & $102 \mathrm{bD}$ & $111 \mathrm{bE}$ & $60 \mathrm{bA}$ & $69 \mathrm{bB}$ \\
$\mathrm{A}$ & $117 \mathrm{aE}$ & $71 \mathrm{aB}$ & $51 \mathrm{aA}$ & $88 \mathrm{aC}$ & $99 \mathrm{aD}$ & $50 \mathrm{aA}$ & $48 \mathrm{aA}$ \\
\hline
\end{tabular}

${ }^{2}$ Interaction between rootstock and $\mathrm{N}$ forms was significant at $P=0.01$.

"Malus prunifolia.

${ }^{x}$ Mean separation in columns (lowercase letters) by Duncan's multiple range test, $P=0.05$.

"Mean separation in rows (uppercase letters) by Duncan's multiple range test, $P=0.05$.

Table 3. Shoot growth of young 'Fuji' apple trees grafted on eight rootstock fed with T, A, or AT.

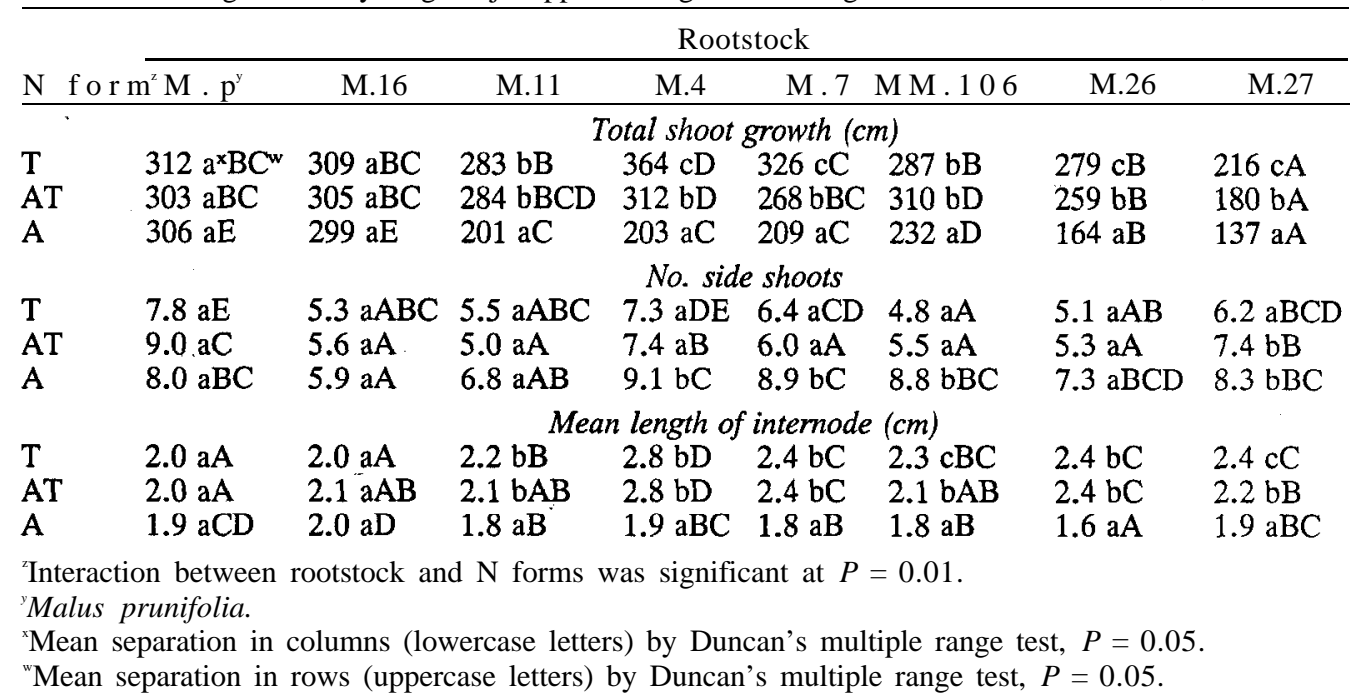

the six rootstock, not including $M$. prunifolia, the mean growth was significantly enhanced by T relative to A. For shoot growth of M. 11 and M.27, treatments T and AT were similar, while shoot lengths of M.4, M.7, M.26, and MM.106 in treatment AT were intermediate between those in treatments $\mathrm{T}$ and $\mathrm{A}$.

'Fuji' trees grafted on nine rootstock. Extension growth of 'Fuji' trees grafted on nine rootstock showed similar trends as those with ungrafted rootstock. Except for two invigorating rootstock, $M$. prunifolia and M.16, the total shoot growth on the other six rootstock was significantly longer in treatment $\mathrm{T}$ than in A (Table 3). In treatment AT, the total growth on M.7, M. 11, M.26, and MM.106 was similar to that of treatment T, while growth on M.4 and M.27 was intermediate. Ammonium $\mathrm{N}$ increased. the number of side shoots and reduced internodal lengths on noninvigorating rootstock compared to $\mathrm{NO}_{3}-\mathrm{N}$ (Table 3). Data for the M.9 rootstock are not presented because half of the trees showed abnormal budbreak and most buds were severely damaged. However, tree growth was similarly reduced by treatments A and AT as in the other rootstock.

More flowering buds were formed on M.4, M.7, M.11, M.26, M.27, and MM.106 than on M. prunifolia and M.16 (Table 4). With the former six rootstock, flowering was more enhanced with A than with $\mathrm{T}$ because more axillary flower buds were formed (Table 4). In these six rootstock, the percentage of flowering buds relative to the total number of emerged buds were also higher with treatment A than with T (Table 4). In $M$. prunifolia and M.16, flowering was meager, and the ratio was not affected by the $\mathrm{N}$ forms.

Cytokinin activity. Cytokinin-like activity in the rootstock xylem sap was detected only at Rfs 0.7 to 0.8 , regardless of root- stock cultivars and N treatment. In M.7, MM. 106, M. 11, M.4, M.26, and M.27, but not M. prunifolia, trees that were treated with $\mathrm{A}$ and AT, cytokinin activity was significantly increased compared to those treated with $\mathrm{T}$ (Table 5). Cytokinin activity in M. prunifolia was very low at either $\mathrm{N}$ treatment. With grafted 'Fuji' trees, cytokinin activity also was detected at Rfs 0.7 to 0.8 , as in the case of ungrafted rootstock (Fig. 1). Again, with the trees on invigorating rootstock, M. prunifolia and M. 16, no differences in cytokinin activities were found among treatments, but trees on M.7, MM.106, M.11, M.4, M.26, M,9, and M.27 showed higher cytokinin activity when $\mathrm{N}$ was supplied as A or as AT. Greatest cytokinin activity was detected with the most dwarfing rootstock, M.9 and M.27.

Gibberellin activity. Two obvious peaks of the gibberellinlike activity were detected at Rfs 0.3 to 0.4 and 0.7 to 0.8 in xylem sap of ungrafted rootstock and in grafted 'Fuji' trees. Much higher activity was detected at lower Rfs in M. prunifolia regardless of $\mathrm{N}$ treatments (Table 5). With other rootstock, activity at lower Rfs was much higher than at higher Rfs when they were fed $\mathrm{T}$, while the activity at higher Rfs was much higher when A was fed. When both $\mathrm{N}$ forms were fed simultaneously (AT), intermediate activity appeared at the two Rf zones. With grafted trees, the M. 16 rootstock responded like M. prunifolia, and M.9, like other dwarfing rootstock (Fig. 2). In trees on $M$. prunifolia and M. 16, the activity at lower Rfs were much higher than those at higher Rfs, and the trend was not affected by $\mathrm{N}$ form. In trees on the other seven rootstock, the activity at lower Rfs was prominent when $\mathrm{T}$ was fed, while A greatly augmented the activity at higher Rfs while lowering those at lower Rfs. 
Table 4. The flowering of young 'Fuji' apple trees grafted on eight rootstock fed with T, A, or AT.

\begin{tabular}{|c|c|c|c|c|c|c|c|c|}
\hline \multirow[b]{2}{*}{$\mathrm{N}^{\text {form }}{ }^{2}$} & \multicolumn{8}{|c|}{ Rootstocks } \\
\hline & M.p. $\mathrm{p}^{\mathrm{y}}$ & M.16 & M.11 & M.4 & M.7 & MM.106 & M.26 & M.27 \\
\hline & \multicolumn{8}{|c|}{ No. terminal flowering buds } \\
\hline $\mathrm{T}$ & $0.5 \mathrm{a}^{\mathrm{x}} \mathrm{A}^{\mathrm{w}}$ & $0.7 \mathrm{aA}$ & $1.1 \mathrm{aAB}$ & $1.0 \mathrm{aA}$ & $0.9 \mathrm{aA}$ & $2.4 \mathrm{aC}$ & $1.7 \mathrm{aB}$ & $4.0 \mathrm{aD}$ \\
\hline AT & $0.3 \mathrm{aA}$ & $0.6 \mathrm{aAB}$ & $1.0 \mathrm{aBC}$ & $1.0 \mathrm{aBC}$ & $1.4 \mathrm{abC}$ & $2.6 \mathrm{aD}$ & $1.4 \mathrm{aC}$ & $4.2 \mathrm{aE}$ \\
\hline A & $0.8 \mathrm{aAB}$ & $0.6 \mathrm{aA}$ & $1.5 \mathrm{aBC}$ & $1.2 \mathrm{aABC}$ & $1.9 \mathrm{bBC}$ & $2.4 \mathrm{aD}$ & $3.2 \mathrm{bE}$ & $3.9 \mathrm{aE}$ \\
\hline & \multicolumn{8}{|c|}{ No. axillary flowering buds } \\
\hline $\mathrm{T}$ & $1.1 \mathrm{aA}$ & $0.8 \mathrm{aA}$ & $0.7 \mathrm{aA}$ & $0.6 \mathrm{aA}$ & $4.6 \mathrm{aB}$ & $9.7 \mathrm{aD}$ & $4.4 \mathrm{aB}$ & $7.3 \mathrm{aC}$ \\
\hline AT & $1.1 \mathrm{aA}$ & $1.1 \mathrm{aA}$ & $6.2 \mathrm{bBC}$ & $5.3 \mathrm{bB}$ & $7.7 \mathrm{bB}$ & $12.2 \mathrm{bE}$ & $10.0 \mathrm{bD}$ & $6.8 \mathrm{aC}$ \\
\hline A & $1.2 \mathrm{aA}$ & $1.0 \mathrm{aA}$ & $8.0 \mathrm{bBC}$ & $8.3 \mathrm{cB}$ & $13.7 \mathrm{cC}$ & $16.9 \mathrm{cE}$ & $14.0 \mathrm{cC}$ & $15.6 \mathrm{bD}$ \\
\hline & \multicolumn{8}{|c|}{ Flowering buds as a percentage of emerged buds } \\
\hline $\mathrm{T}$ & $2.1 \mathrm{aA}$ & $2.0 \mathrm{aA}$ & $2.4 \mathrm{aA}$ & $2.3 \mathrm{aA}$ & $7.4 \mathrm{aC}$ & $11.5 \mathrm{aD}$ & $5.5 \mathrm{aB}$ & $21.2 \mathrm{aE}$ \\
\hline AT & $1.4 \mathrm{aA}$ & $2.3 \mathrm{aA}$ & $5.3 \mathrm{bB}$ & $6.5 \mathrm{bC}$ & $8.2 \mathrm{aD}$ & $24.1 \mathrm{bF}$ & $11.8 \mathrm{bE}$ & $23.0 \mathrm{aF}$ \\
\hline A & $2.1 \mathrm{aA}$ & $2.1 \mathrm{aA}$ & $14.1 \mathrm{cC}$ & $7.8 \mathrm{cB}$ & $20.7 \mathrm{bD}$ & $29.0 \mathrm{cF}$ & $22.7 \mathrm{cE}$ & $69.0 \mathrm{bG}$ \\
\hline
\end{tabular}

Interaction between rootstock and $\mathrm{N}$ forms was significant at $P=0.01$.

"Malus prunifolia.

${ }^{x}$ Mean separation in columns (lowercase letters) by Duncan's multiple range test, $P=0.05$.

"Mean separation in rows (uppercase letters) by Duncan's multiple range test, $P=0.05$.

Table 5. The cytokinin- and gibberellin-like activity in the extracted sap from shoot xylem of seven ungrafted rootstock fed with $\mathrm{T}, \mathrm{A}$, or AT.

\begin{tabular}{|c|c|c|c|c|c|c|c|}
\hline \multirow[b]{2}{*}{$\mathrm{N}$ form $^{2}$} & \multicolumn{7}{|c|}{ Rootstocks } \\
\hline & M.p. & M.11 & M.4 & M.7 & MM.106 & M.26 & M.27 \\
\hline \multicolumn{8}{|c|}{ Cytokinin-like activity (Rfs $0.7-0.8$ ) (nmol BA/100 g shoot fresh wt) } \\
\hline $\mathrm{T}$ & $0.003 \mathrm{a}^{\times} \mathrm{B}^{\mathrm{v}}$ & $0.003 \mathrm{aAB}$ & $0.002 \mathrm{aAB}$ & $0.002 \mathrm{aAB}$ & $0.001 \mathrm{aAB}$ & $0.002 \mathrm{aAB}$ & $0.001 \mathrm{aA}$ \\
\hline $\mathrm{AT}$ & $0.004 \mathrm{aA}$ & $0.908 \mathrm{bB}$ & $0.389 \mathrm{bB}$ & $0.373 \mathrm{bB}$ & $0.201 \mathrm{bB}$ & $0.763 \mathrm{bB}$ & $0.763 \mathrm{bB}$ \\
\hline A & $0.005 \mathrm{aA}$ & $0.491 \mathrm{bB}$ & $0.844 \mathrm{bB}$ & $0.830 \mathrm{bB}$ & $0.763 \mathrm{bB}$ & $0.844 \mathrm{bB}$ & $1.019 \mathrm{bB}$ \\
\hline \multicolumn{8}{|c|}{ Gibberellin-like activity (Rfs $0.3-0.4)\left(n m o l ~ G A_{3} / 100 \mathrm{~g}\right.$ shoot fresh wt) } \\
\hline $\mathrm{T}$ & $0.578 \mathrm{aC}$ & $0.228 \mathrm{cBC}$ & $0.103 \mathrm{bA}$ & $0.170 \mathrm{cBC}$ & $0.231 \mathrm{bBC}$ & $0.201 \mathrm{cBC}$ & $0.057 \mathrm{cA}$ \\
\hline $\mathrm{AT}$ & $0.465 \mathrm{aC}$ & $0.006 \mathrm{bA}$ & $0.004 \mathrm{aAB}$ & $0.048 \mathrm{bB}$ & $0.031 \mathrm{abAB}$ & $0.003 \mathrm{bA}$ & $0.003 \mathrm{bA}$ \\
\hline A & $0.393 \mathrm{aC}$ & $0.001 \mathrm{aAB}$ & $0.001 \mathrm{cBC}$ & $0.001 \mathrm{aB}$ & $0.004 \mathrm{aB}$ & $0.001 \mathrm{aAB}$ & $0.000 \mathrm{aA}$ \\
\hline \multicolumn{8}{|c|}{ Gibberellin-like activity (Rfs $0.7-0.8)\left(\right.$ nmol $G A_{3} / 100 \mathrm{~g}$ shoot fresh wt) } \\
\hline $\mathbf{T}$ & $0.003 \mathrm{aA}$ & $0.002 \mathrm{aA}$ & $0.000 \mathrm{aA}$ & $0.001 \mathrm{aA}$ & $0.002 \mathrm{aA}$ & $0.001 \mathrm{aA}$ & $0.002 \mathrm{aA}$ \\
\hline AT & $0.002 \mathrm{aA}$ & $0.069 \mathrm{bBC}$ & $0.003 \mathrm{aA}$ & $0.028 \mathrm{bB}$ & $0.058 \mathrm{bBC}$ & $0.039 \mathrm{bB}$ & $0.173 \mathrm{bC}$ \\
\hline A & $0.004 \mathrm{aA}$ & $0.272 \mathrm{cB}$ & $0.293 \mathrm{bB}$ & $0.419 \mathrm{cB}$ & $0.307 \mathrm{cB}$ & $0.316 \mathrm{cB}$ & $0.320 \mathrm{bB}$ \\
\hline
\end{tabular}

${ }^{2}$ Interaction between rootstock and $\mathrm{N}$ forms was significant at $P=0.01$.

${ }^{y}$ Malus prunifolia.

'Mean separation in columns (lowercase letters) by Duncan's multiple range test, $P=0.05$, with three replications.

"Mean separation in rows (uppercase letters) by Duncan's multiple range test, $P=0.05$, with three replications.

\section{Discussion}

This study has clearly shown that the growth and flowering responses of apples to the form of supplied $N$ vary with rootstock when grown in sand culture in pots. In 'Fuji' trees grafted on dwarfing rootstock, ammonium nitrogen reduced extension growth and internode length while increasing the incidence of side growth and flowering buds. Grasmanis and his coworkers reported similar results with 'Jonathan' apple grafted on a semidwarfing rootstock, MM. 104 (Grasmanis and Edwards, 1974; Grasmanis and Leeper, 1965, 1967). However, trees on invigorating rootstock, such as M. prunifolia and M. 16, were slightly affected by the form of supplied N. This result indicates that the influence of ammonium nitrogen on the growth and flowering in apple trees is concerned with the vigor-controlling potential of the rootstock.

In apple roots, both nitrate and ammonium ions can be readily absorbed if either ion is present in nutrient solution (Frith and Nichols, 1975; Tromp and Ovaa, 1979). Both absorbed nitrate and ammonium are assimilated into amino acids and their derivative amides in the roots. Asparagine is considered to be the main transport form and arginine the major storage form of $\mathrm{N}$ (Tromp and Ovaa, 1979). Ammonium-treated trees contain higher concentrations of asparagine and arginine in the new growth and stem bark than do nitrate-treated trees (Tromp and Ovaa, 1979). Therefore, amino acids and their derivatives, especially arginine and polyamides, might be involved in controlling flower formation of apple trees (Buban et al., 1978; Rohozinski et al., 1986). Mineral analyses of leaves showed that total N content of 'Fuji' trees, except for trees on M. prunifolia and M.16, were higher with treatment $\mathrm{A}$ than with treatment $\mathrm{T}$ (data not shown). With these trees, leaves were darker in the $\mathrm{NH}_{4}-\mathrm{N}$ treatment. Higher $\mathrm{N}$ content in the leaves of ammonium-treated trees may suggest the higher amounts of amino acids in ammonium-treated than in nitrate-treated trees.

Flowering data were not obtained with trees on M.9 in either treatment due to their abnormal budbreak, probably because the trees were infected with stalk-end rot (Phomopsis mali Roberts). 


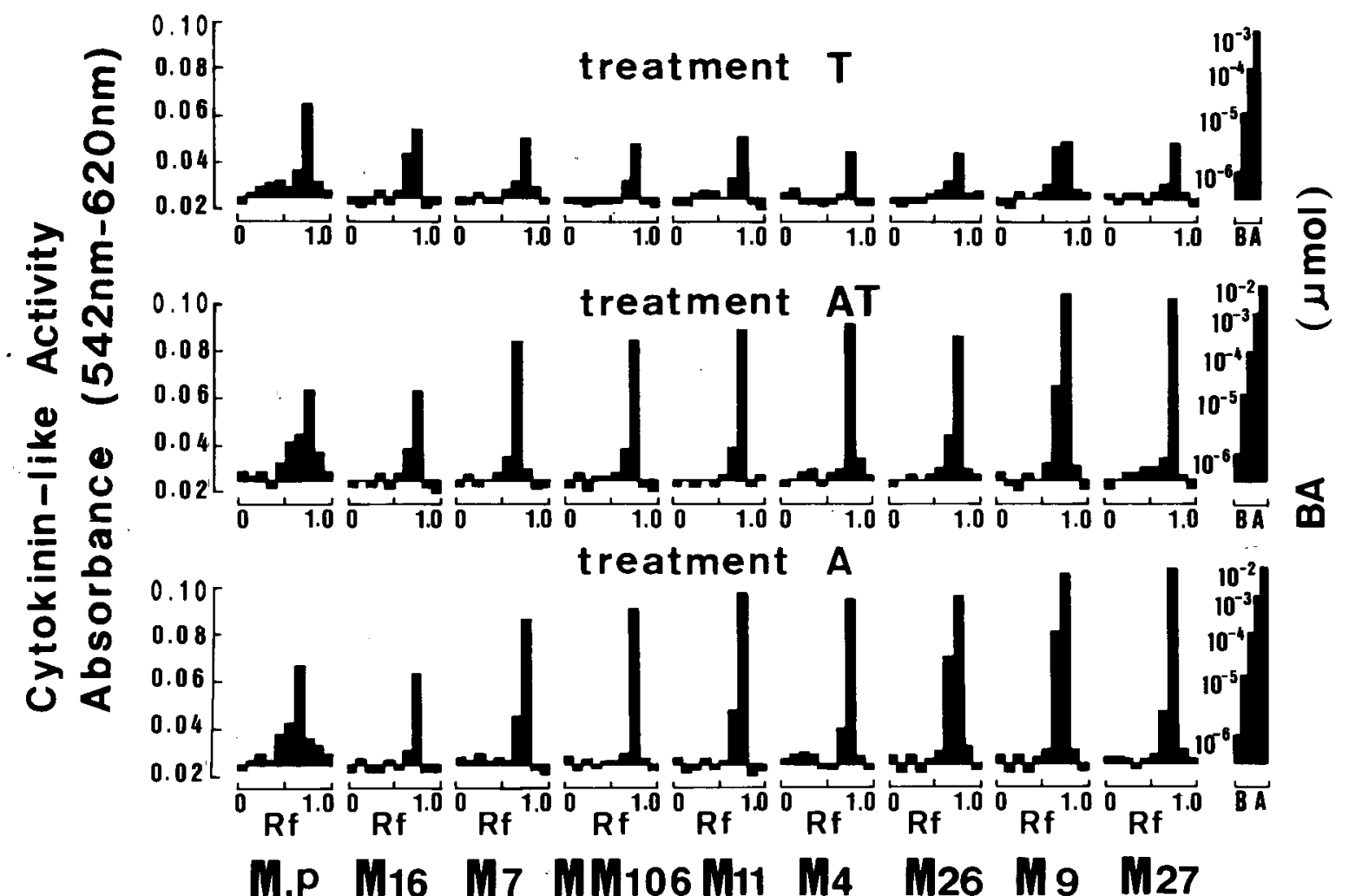

Fig. 1. Cytokinin-like activity in the xylem sap of 'Fuji' apples grafted on nine rootstock as affected by T, A, or AT application. The histograms show the activities in the sap equivalent to $40 \mathrm{~g}$ of stem fresh weight.

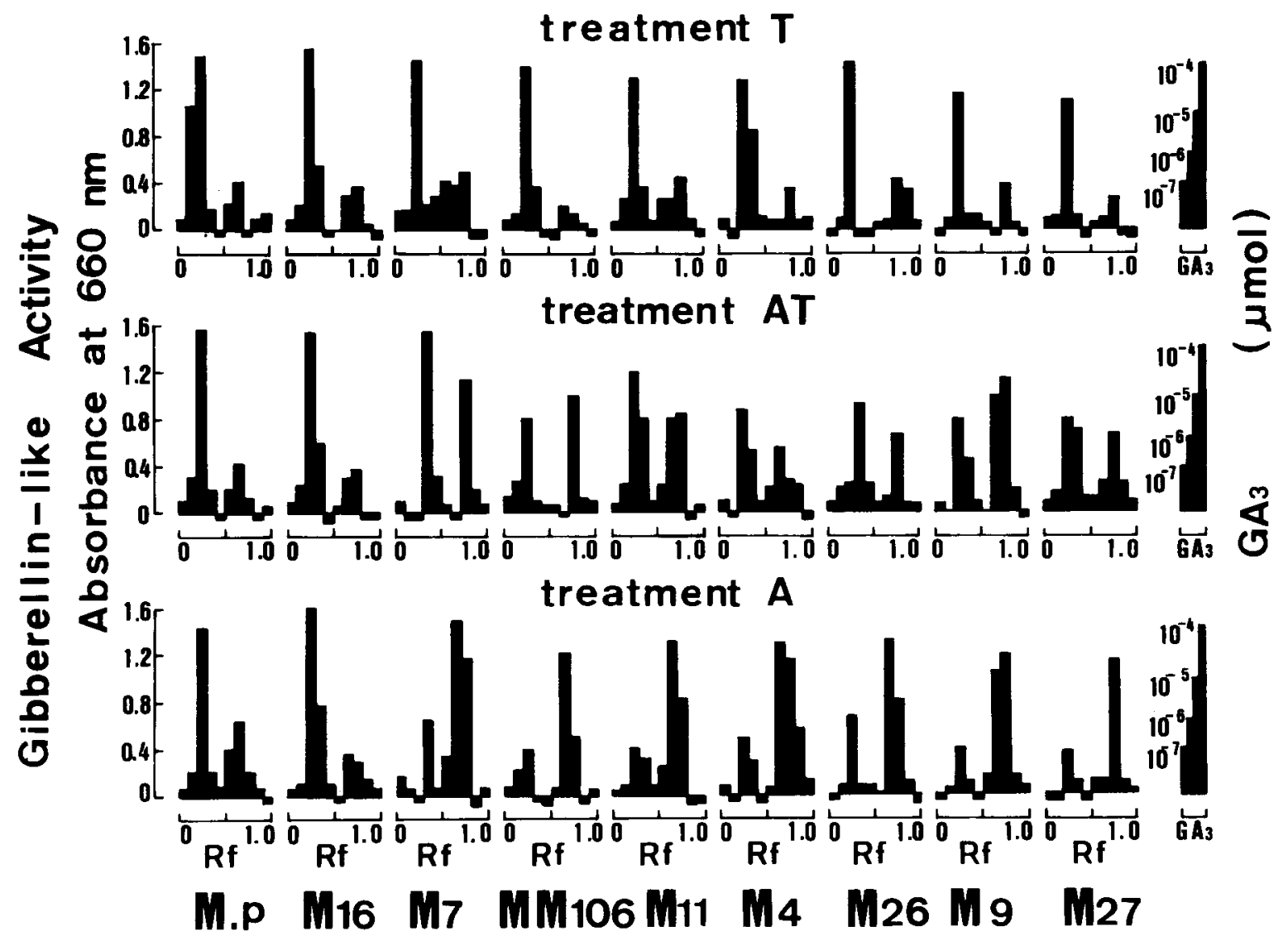

Fig. 2. Gibberellin-like activity in the xylem sap of 'Fuji' apples grafted on nine rootstocks as affected by T, A, or AT application. The histograms show the activities in the sap equivalent to $20 \mathrm{~g}$ of fresh weight of stem. 
Some trees on M.26 and M.27 showed similar symptoms. This problem may have been caused by the high level of $\mathrm{N}$ supplied or by fertilization that was continued too late in the season, either of which might have resulted in unhardened susceptible wood tissues in these dwarfing rootstock.

Enhancement of side shoots and flowering by ammonium implies the involvement of cytokinins in these phenomena. Buban et al. (1978) demonstrated that M.7 trees supplied with ammonium had a higher zeatin concentration in xylem sap than those given nitrate. It is well known that cytokinins are synthesized in root tips and that gibberellins are synthesized or converted from their precursors in the roots (Lockard and Schneider, 1981). Our study showed that fertilization with ammonium nitrogen increased cytokinin activity in xylem sap extracted from stems of several dwarfing apple rootstock and from 'Fuji' trees grafted on them. However, invigorating rootstock, such as $M$. prunifolia or 'Fuji' trees grafted on M. prunifolia or M.16, responded similarly to both forms of $\mathrm{N}$, without an increase in cytokinin activity. Thus, the fact that ammonium nitrogen reduced vegetative growth and increased flowering on dwarfing rootstock may be partly explained by increased activity in cytokinins. It has been demonstrated with citrus and grapes (Vitis vinifera L.) that cytokinins are important in flower initiation (Monselise and Halevy, 1964; Mullins, 1986; Srinivasan and Mullins, 1981). It has also been shown with apples that spray treatments of zeatin and BA several weeks after full bloom greatly increased flowering the next spring (McLaughlin and Greene, 1984; Ramirez and Hoad, 1981).

Gibberellins are produced in high quantities in the developing apple seeds, diffuse out from the fruit, and inhibit flowering in the spurs, thus causing alternate bearing in some cultivars (Hoad, 1978). In fact, there is ample evidence that gibberellins applied exogenously during the growing season inhibit flower initiation in many fruit species (Hoad, 1984). Tromp (1982), however, reported that exogenously applied $\mathrm{GA}_{3}$ and $\mathrm{GA}_{7}$ strongly inhibited flowering, while $\mathrm{GA}_{4}$ gave almost no reduction in flowering in apple trees. Later, Looney et al. (1985) demonstrated that $\mathrm{GA}_{4}$ and its isomer C-3 epi-GA ${ }_{4}$ even stimulated flowering in apple trees. In our experiment, fertilization with ammonium, which stimulated flowering in dwarfing rootstock, greatly heightened gibberellin-like activity in the higher Rf zone while reducing those in the lower $\mathrm{Rf}$ zone. This difference suggests that gibberellin(s) in the higher Rf zone may be closely associated with stimulated flowering in ammonium-fed apple trees. Lower activity in the lower Rf zone may also be related to the reduction in vegetative growth of ammonium-fed trees.

Koshioka et al. (1985) demonstrated the presence of $\mathrm{GA}_{1}$, $\mathrm{GA}_{9}, \mathrm{GA}_{19}$, and $\mathrm{GA}_{20}$ in apple shoot tips. Presence of $\mathrm{GA}_{4}$ and GA, is also mentioned in apple shoot tips (Looney et al., 1988). Gibberellins in apple xylem sap have not yet been identified, but probably include the above. According to MacMillan et al. (1961), who used the same paper chromatographic system as we used here, Rfs of $\mathrm{GA}_{1}, \mathrm{GA}_{3}, \mathrm{GA}_{4}$, and $\mathrm{GA}_{7}$ were 0.48 , $0.49,0.72$, and 0.71 , respectively. The barley endosperm bioassay is known to respond specifically to C-3 hydroxy GAs, such as $\mathrm{GA}_{1}, \mathrm{GA}_{3}, \mathrm{GA}_{4}$, and $\mathrm{GA}_{7}$, but not to other GAs having no hydroxyl at the C-3 position (Crozier et al., 1970). From these lines of evidence, the gibberellins at lower Rfs in our experiment might include a highly polar $\mathrm{GA}_{1}$, while that at higher Rfs could be nonpolar $\mathrm{GA}_{4}$ or $\mathrm{GA}_{7}$. Detailed characterization is needed.

'Fuji' trees on invigorating rootstock, M. prunifolia and M.16, responded in the same manner to nitrate and ammonium nitrogen and showed no difference in cytokinin and gibberellin ac- tivity. This finding coincides with the fact that almost no flowering occurred in response to either form of $\mathrm{N}$ with the invigorating rootstock trees. Robitaille and Carlson (1971) reported that in 'Red Prince Delicious' apple trees the promotive effects of $\mathrm{GA}_{3}$ on extension growth were more obvious as rootstock vigor decreased, and, moreover, dwarfed trees responded more quickly to abscisic acid than vigorous ones. Thus, invigorating rootstock seemed to respond weakly to stimuli leading to retarded growth and accelerated flowering. Dwarfing rootstock, however, responded quickly to such stimuli.

\section{Literature Cited}

Biddington, N.L. and T.H. Thomas. 1973. A modified Amaranthus betacyanin bioassay for the rapid determination of cytokinins in plant extract. Planta 111:183-186.

Buban, T., V. Varga, J. Tromp, and J. Bruinsma. 1978. Effects of ammonium and nitrate nutrition on the levels of zeatin and amino nitrogen in xylem sap of apple rootstock. Z. Pflanzenphysiol. 89:289295.

Crozier, A., C.C. Kuo, R.C. Durley, and R.P. Pharis. 1970. The biological activities of 26 gibberellins in nine plant bioassays. Can. J. Bet. 48:867-877.

Frith, G.J.T. and D.G. Nichols. 1975. Preferential assimilation of ammonium ions from ammonium nitrate solutions by apple seedlings. Physiol. Plant. 33:247-250.

Grasmanis, V.O. and G.R. Edwards. 1974. Promotion of flower initiation in apple trees by short exposure to the ammonium ion. Austral. J. Plant Physiol. 1:99-105.

Grasmanis, V.O. and G.W. Leeper. 1965. Ammonium versus nitrate in culture solutions. Agrochimica 10:54-63.

Grasmanis, V.O. and G.W. Leeper. 1967. Ammonium nutrition and flowering of apple trees. Austral. J. Biol. Sci. 20:751-767.

Grasmanis, V.O. and D.J.D. Nicholas. 1971. Annual uptake and distribution of $\mathrm{N}^{15}$-labeled ammonia and nitrate in young Jonathan/ MM104 apple trees grown in solution cultures. Plant\& Soil 35:95112.

Greene, D.W. 1975. Cytokinin activity in the xylem sap and extract of MM 106 apple rootstock. HortScience 10:73-74.

Hoad, G.V. 1978. The role of seed derived hormones in the control or flowering in apple. Acts Hort. 80:93-103.

Hoad, G.V. 1984. Hormonal regulation of fruit-bud formation in fruit trees. Acts Hort. 149: 13-23.

Ibrahim, I.M. and M.N. Dana. 1971. Gibberellin-like activity in apple rootstock. HortScience 6:541-542.

Jones, O.P. 1973. Effect of cytokinins in xylem sap from apple trees on apple shoot growth. J. Hort. Sci. 48:181-188.

Jones, O.P. 1986. Endogenous growth regulators and rootstoc!+cion interactions in apple and cherry trees. Acts Hort. 179: 177-184.

Jones, O.P. and H.J. Lacey. 1968. Gibberellin-like substances in the transpiration stream of apple and pear trees. J. Expt. Bet. 19:526531.

Koshioka, M., J.S. Taylor, G.R. Edwards, N.E. Looney, and R.P. Pharis. 1985. Identification of gibberellins $A_{19}$ and $A_{20}$ in vegetative apple tissue. Agr. Biol. Chem. 49:1223-1226.

Lee, C. H., A. Sugiura, and T. Tomana. 1982. Effect of flooding on the growth and some physiological changes of young apple rootstock (in Japanese with English summary). J. Jpn. Soc. Hort. Sci. 51:270-277.

Lockard, R.G. and G.W. Schneider. 1981. Stock and scion growth relationships and. the dwarfing mechanisms in apple. Hort. Rev. 3:315-375.

Looney, N. E., R.P. Pharis, and M. Noms. 1985. Promotion of flowering in apple trees with gibberellin $\mathrm{A}_{4}$ and C-3 epi-gibberellin $\mathrm{A}_{4}$. Planta 165:292-294.

Looney, N. E., J.S. Taylor, and R.P. Pharis. 1988. Relationship of endogenous gibberellin and cytokinin levels in shoot tips to apical form in four strains of 'McIntosh' apple. J. Amer. Soc. Hort Sci. 113:395-398. 
MacMillan, J., J.C. Seaton, and P.J. Suter. 1961. Isolation and structures of gibberellins from higher plants, p. 18-25. In: R.F. Gould (cd.). Advances in chemistry series, 28. Gibberellins. Amer. Chem. Soc., Washington, D.C.

McLaughlin, J.M. and D.W. Greene. 1984. Effects of BA, GA ${ }_{4+7}$, and daminozide on fruit set, fruit quality; vegetative growth, flower initiation, and flower quality of 'Golden Delicious' apple. J. Amer. Soc. Hort. Sci. 109:34-39.

Monselise, S.P. and A.H. Halevy. 1964. Chemical inhibition and promotion of citrus flower bud induction. Proc. Amer. Soc. Hort. Sci. 84:141-146.

Moreno, J.and J. L. Garcia-Martinez. 1980. Extraction of tracheal sap from citrus and analysis of its nitrogenous compounds. Physiol. Plant. 50:298-303.

Mullins, M.G. 1986. Hormonal regulation of flowering and fruit set in the grapevine. Acta Hort. 179:309-315.

Nicholls, P.B. and L.G. Paleg. 1963. Abarley endosperm bioassay for gibberellins. Nature 199:823-824.

Ramirez, H. and G.V. Hoad. 1981. Effects of growth substances on fruit-bud initiation in apple. Acta Hort. 120:131-136.

Robitaille, H. and R.F. Carlson. 1971. Response of dwarfed apple trees to stem injection of gibberellic and abscisic acids. HortScience $6: 539-540$.
Rohozinski, J., G.R. Edwards, and P. Hoskyns. 1986. Effects of brief exposure to nitrogenous compounds on floral initiation in apple trees. Physiol. Veg. 24:673-677.

Sadamori, S. and H. Murakami. 1952. Studies on rootstock of apples I. Effect of soil moisture on the growth of several Malus seedlings (in Japanese). J. Jpn. Soc. Hort. Sci. 21:107-112.

Saidha, T., E.E. Goldschmidt, and S.P. Monselise. 1983. Endogenous growth regulators in tracheal sap of citrus. HortScience 18:231-232.

Shear, C.B. and M. Faust. 1971. Nutritional factors influencing the mineral content of apple leaves. J. Amer. Soc. Hort. Sci. 96:234240.

Srinivasan, C. and M.G. Mullins. 1981. Induction of precocious flowering in grapevine seedling by growth regulators. Agronomic 1:15 .

Stevens, G. A., Jr., and M.N. Westwood. 1984. Fruit set and cytokinin-like activity in the xylem sap of sweet cherry (Prunus avium) as affected by rootstock. Physiol. Plant. 61:464-468.

Tromp, J. 1982. Flower-bud formation in apple as-affected by various gibberellins. J. Hort. Sci. 57:277-282.

Tromp, J. and J.C. Ovaa. 1979. Uptake and distribution of nitrogen in young apple trees after application of nitrate or ammonium, with special reference to asparagine and arginine. Physiol. Plant. 45:2328. 